\title{
McCarthyism, Christianity, and the Mafia: Elia Kazan's On the Waterfront Reconsidered
}

\author{
ROBERT J. CARDULLO \\ University of Michigan
}

\begin{abstract}
Whether one sees it, finally, as a moral tale, a semi-documentary crime melodrama, a social-problem picture, a boxing film manqué, a Christian allegory, a political allegory, or a revenge fantasy, On the Waterfront has found its way into the ranks of cinema classics-where it remains, over sixty years after its initial release. This essay reconsiders the following elements in On the Waterfront: its historical context and political overtones in the McCarthyite America of the early 1950s; the movie's thoroughgoing Christian symbolism; and the role of organized crime both inside and outside the film's drama. In the process, the author "names names" and investigates their role in bringing this important work to fruition: Elia Kazan, Arthur Miller, Budd Schulberg, Malcolm Johnson, and Marlon Brando.
\end{abstract}

Keywords: On the Waterfront; Elia Kazan; McCarthyism; American communism; Christianity; organized crime.

\section{Resumen}

Ya sea desde la óptica de un cuento moral o desde la de un melodrama de crimen semidocumental o de una representación de un problema social, o como una película de boxeo o una alegoría cristiana o política o como una fantasía de venganza, La ley de la calle (On the Waterfront) ha encontrado su camino en las filas de los clásicos del cine, donde permanece, más de sesenta años después de su lanzamiento inicial. Este ensayo analiza tanto su contexto histórico y las connotaciones políticas en la América McCarthy de principios de los años cincuenta como el simbolismo cristiano completo de la película; y el papel del crimen organizado tanto dentro como fuera del drama de la película. En esta tarea, se "nombran nombres" y se investiga su papel para llevar a cabo este importante trabajo: Elia Kazan, Arthur Miller, Budd Schulberg, Malcolm Johnson y Marlon Brando.

Palabras clave: On the Waterfront, Elia Kazan, McCarthyismo, Comunismo americano, cristianismo, crimen organizado. 
The genesis of On the Waterfront (1954) is nearly as fascinating as the film itself. In April of 1948 a New York dock hiring-boss was murdered; it was the second such killing in a short time. Reporter Malcolm Johnson was assigned by the nowdefunct New York Sun to cover the story, and Johnson's initial inquiries developed into a full-scale investigation of waterfront crime. His findings were revealed in a series of twenty-four, Pulitzer Prize-winning articles called "Crime on the Waterfront," published in the Sun between November 8 and December 10, 1948. The exposé revealed rampant thievery, bribery, shakedowns, kickbacks, payoffs, shylocking, and murder-all of which were costing the port of New York millions of dollars each year in lost shipping trade.

At this time, Elia Kazan, the director of On the Waterfront-his tenth feature of an eventual nineteen films - was among the most successful and influential directors on Broadway and in Hollywood. From his work on the Group Theatre's production of Clifford Odets's Golden Boy (1937) to his direction of Tennessee Williams' A Streetcar Named Desire (play, 1947; film, 1951) and of Arthur Miller's All My Sons (1947) and Death of a Salesman (1949), Kazan had helped to shape studies of inhuman exploitation, bestial degradation, and greedy materialism, as well as to craft statements concerning moral responsibility. And, though On the Waterfront was self-generated, an independent film produced outside studio control, it evolved from Kazan's proven aptitude for delivering "hard-hitting" melodramas for Twentieth Century-Fox, movies that earnestly scratched the itchy surfaces of identifiable social issues: anti-Semitism in Gentleman's Agreement (1947), racism in Pinky (1949), and, more ambitiously, the nature of revolution in Viva Zapata! (1952). Despite his considerable reputation, however, Kazan had fallen into disfavor with many for his cooperation with the House Un-American Activities Committee (HUAC) in 1952 - in two separate appearancesduring its investigations of Communist activity in the film industry.

The initial idea for a waterfront drama came from a person who had nothing to do with the finished, 1954 film. In 1949, Arthur Miller, flushed with the success of two Broadway plays (All My Sons and Death of a Salesman), directed his considerable talent toward the social struggle then being waged on the Brooklyn docks. His play The Bottom of the River was to tell the story of real-life militant trade unionist Peter Panto, who in the late 1930s tried to organize dissident longshoremen in Brooklyn's Red Hook district. But mobsters inside the dockworkers' union feared Panto's rapid rise to popularity and had him killed, dumping his body into the East River. In 1951, when Miller's script, now retitled The Hook (and supplemented by material from Malcolm Johnson's newspaper articles), was finished, he contacted his colleague Kazan and suggested that they work jointly on a movie version. The Hook was never produced, however, due to HUAC pressure on Columbia Pictures' studio chief Harry Cohn, who told Miller to change the villains from corrupt union officials and gangsters to evil Communists so that the movie would have a "pro-American" feel. Miller refused to do this and pulled out as screenwriter.

Arthur Miller was then replaced by Budd Schulberg. The author of the screenplay for On the Waterfront (as suggested, again, by Johnson's articles) himself was an established author who had won esteem for his novel about the motion-picture business, What Makes Sammy Run? (1941), and for his hard-hitting fiction exposé of the prizefighting business, The Harder They Fall (1947), as well as for a bestseller about two Hollywood screenwriters called The Disenchanted (1950). Like Kazan, Schulberg had also flirted with Communism in the 1930s and voluntarily testified before HUAC in 1951, admitting Party membership, explaining Party methods of controlling dissident members, and naming former associates. 
Although the Waterfront project was supported by the combined expertise of Kazan and Schulberg, no Hollywood studio would finance the venture; some argued that the issues were too depressing, others that filming on location (as Kazan wished to do) would be too dangerous, still others that the HUAC-connection of the director and screenwriter would be bad for business. But just as the project began to seem unrealizable, an independent producer named Sam Spiegel accepted the challenge and financed the film (for slightly less than a million dollars), which, in keeping with the documentary nature of its source material, was filmed over thirty-six days on the streets and docks, the alleys and rooftops, of Hoboken, New Jersey, where this particular story takes place. With a singularity of purpose, On the Waterfront was not only to expose the corruption of the waterfront unions but also to reflect the day-to-day struggle for work and dignity among the longshoremen themselves. This the film would do through its protagonist, a slow-witted but sensitive dockworker who, through a strange brew of conscience and vengeance, emerges from the group to break the stranglehold on labor maintained by the corrupt union.

The film's narrative naturally centers on that protagonist: Terry Malloy (played by Marlon Brando, though Hoboken-born Frank Sinatra had been the first choice), a former boxer turned dockworker, who at the start becomes the unwitting pawn in the murder of a fellow longshoreman preparing to testify against gangsters who tyrannize the docks. Through an insistent, reformist priest, Father Barry (Karl Malden), Terry is slowly drawn into a moral dilemma. For his loyalties to the racketeers, led by Johnny Friendly, a.k.a. Michael J. Skelly (Lee J. Cobb, who himself testified before HUAC in 1953) and Terry's brother, Charley (Rod Steiger), have been weakened by the murder. (Schulberg derived Malden's character from that of a tough, profane-mouthed waterfront Catholic priest named Father John M. Corridan; Malloy was modeled after the whistle-blowing longshoreman Anthony DeVincenzo; and Friendly was based both on International Longshoremen's Association boss Michael Clemente and on the mobster Albert Anastasia, the chief executioner of Murder Incorporated, the "enforcement arm" of the Mafia in New York.) The weakening of those loyalties, combined with Terry's growing affection for Edie (Eva Marie Saint, in her first film role) - the sister of the film's first murder victim, Joey Doyle - and the persuasive tactics of Father Barry, gradually draws his allegiance away from the gangsters.

With a neo-Gothic Catholic church hovering behind him, Terry first confesses his culpability in Joey's murder to Father Barry; prodded by the priest, he next confesses to Edie Doyle (who, herself eager to uncover the identity of her brother's murderers, provokes Terry's guilt) as they wander outside the spiked iron fence that encircles the waterfront community, even as a wire-mesh cage encloses Terry's pigeons. But these private confessions give Terry little satisfaction, and Father Barry advises him that confession before a public tribunal will better serve his dockworker "brothers." In love with Edie, manipulated by the priest, and in disfavor with the mob, Terry then undergoes the final stage of his conversion when, following the murder of another longshoreman preparing to testify before the Waterfront Crime Commission ("Kayo" Dugan), his own brother is brutally slain as a warning to him not to open his mouth. Undaunted and seeking revenge, Terry testifies against Friendly and his gang before the Crime Commission and afterwards is ostracized by friends and dockworkers alike as a "stool pigeon."

When Terry subsequently confronts Friendly and his cohorts directly, down at the docks, he is viciously beaten by them after putting up a good fight of his own. Yet, in a final effort of will, and with a handheld camera delivering his dizzy, lurching point of view - as he carries the longshoreman's hook (a suggestion of the cross Christ 
carried); wears a sacred cloth (the jacket previously worn by the two murdered or martyred longshoremen); bleeds about the head (a visual allusion to Christ's crown of thorns) from the beating (comparable to Christ's flagellation) he has just received; and stumbles three times (like Christ on the via dolorosa to his crucifixion) but is nonetheless urged on by the saintly Father Barry and the angelic Edie-Terry leads the rejuvenated flock of longshoremen back to work in an act of defiance against the racketeers.

There are thus three major steps in Terry Malloy's conversion. The first segment of On the Waterfront exposes his associations with the corrupt gang; the second segment depicts Terry's discovery of corruption as well as the extent of his own guilt; and the final segment shows him battling for his own "rights." Each segment has a ritualized scene that summarizes its action. The "shape-up" scene in the first segment discloses the dehumanizing conditions on the docks - conditions that are fostered by union corruption. A union leader throws "brass checks" onto the ground, where longshoremen wrestle to retrieve their guarantee of one day's work. Shown separated from the central scramble here, Terry is given a "cushy" job for having set up Joey Doyle for the "knock-off."

The potency of the "shape-up" scene results from camera positioning. When Big Mac blows his whistle to call the workers, the camera stands behind him, permitting his large figure to obscure the huddled longshoremen. During the scramble for the brass checks, the camera is low to the ground, capturing the strain of facial expressions; character movement is downward, and the camera seems to press the viewer himself against the dirty dockside surface. When Edie, who has come to the "shape-up" to discover the causes of union corruption, tries to retrieve a brass check for her father, she comes into contact with Terry Malloy. He overpowers her and recovers the contested check for a friend, suggesting that muscle alone prevails on the docks. But when Terry learns that his female adversary is the sister of the young man whom he set up for the "knock-off," his conscience convinces him to surrender the brass check to her. In this way the conflict between muscle and morality in On the Waterfront is established.

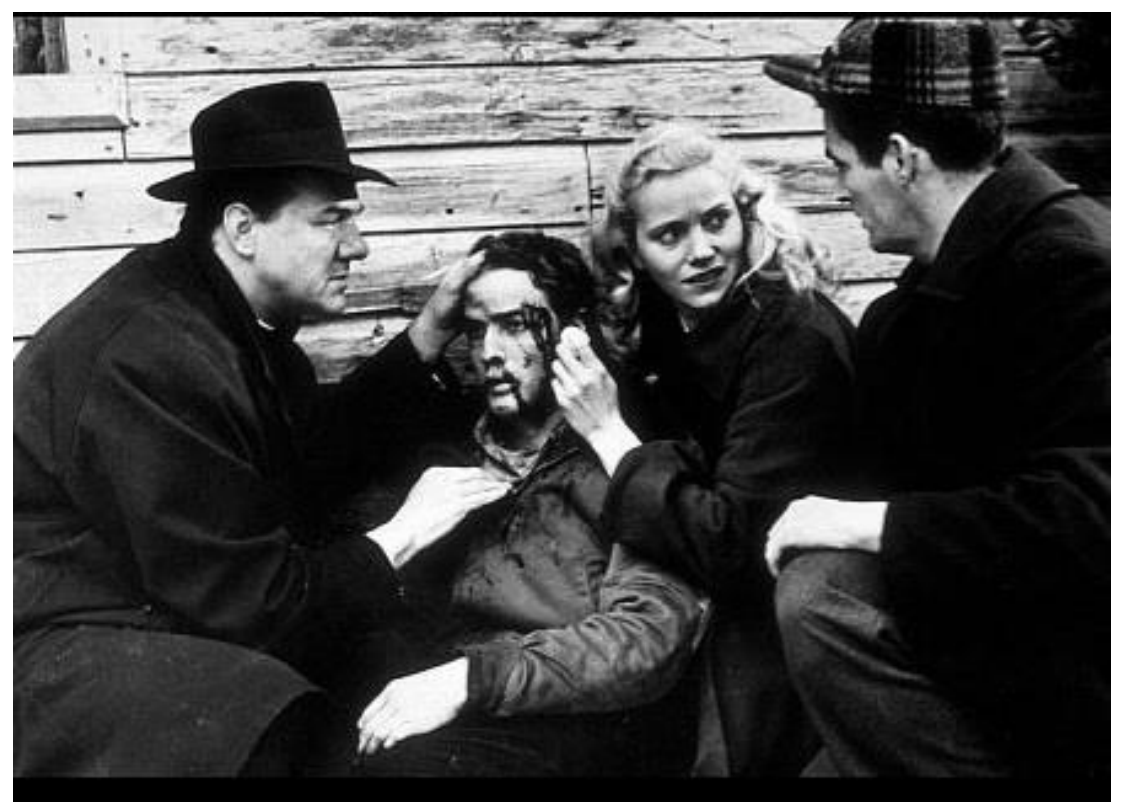

During this encounter between Terry and Edie, the camera first frames Edie and Terry's contest in the foreground, with the longshoremen's struggle pictured in the background. When the couple's scramble gives way to moral considerations on Terry's 
part, the camera changes position, isolation their conversation and implicitly making a special case for these two individuals within the generally demeaning environment of the Hoboken docks. To wit: the moral position embodied by Edie alters the nature of what we see. For the scene as a whole, the camera presents the viewer with the facts of the story (and therefore with a sense of witnessing a real event in the workers' daily lives), the filmmakers' opinion about the story (Mac and his associates have the power, while the dockworkers are oppressed and unorganized), and Terry Malloy's special relationship, as both insider and outsider, to the waterfront conditions that are depicted. Through camera positioning, then, the "shape-up" scene establishes dramatic conflicts, as well as visual motifs, that will be explored as the film progresses.

The second major step in Terry's conversion takes place in the middle of On the Waterfront, during a "martyrdom" scene in a ship's hold that features Father Barry's oration over the dead body of "Kayo" Dugan (whose character, as played by Pat Henning, was based on that of a disciple of Father Corridan named Arthur Browne). During this ritualized segment, the "waterfront priest" pleads with the dockworkers to come forward and speak because their silence only serves the mobsters' selfish interests. Father Barry's emotional words introduce the idea of shared guilt and encourage action to combat and ultimately defeat the corrupt mob. As his shrill accusations resound through the ship's hold, the forces of chaos and brutality (the "mugs" who throw cans and tomatoes at the priest) are silenced when Terry punches out the hoodlum Tillio. With the camera searching high overhead to find Friendly and Charley, it is obvious at this point that the power relationships have not yet changed. But the men begin to realize in the "martyrdom" scene that their silence only serves their oppressors.

While Father Barry speaks here, the shadow of a cross-like form rises on the wall behind him. After his speech, Dugan's body ascends on a sling from the workers' hell (the lower depths of the ship), accompanied by the priest and "Pop" Doyle (Joey's father), two saintly escorts for the workingman's martyr. The men stand with their hats off, unified at least momentarily by this ritual. Whereas the "shape-up" had belittled the dockworkers, this affirmative scene "resurrects" their self-image. The action of the men at the "shape-up" was downward to the ground; during the "martyrdom," the action is upward toward the sources of oppression.

A "testimonial" scene at the hearings of the Waterfront Crime Commission makes up the third major step in Terry Malloy's moral or spiritual conversion and completes the film's structural argument. The rule of law receives reinforcement at this point as Terry confesses to society his unwitting complicity in Joey Doyle's murder at the same time as he indicts Johnny Friendly's gang. At the end, the state's principal investigator thanks Terry profusely, explaining that his actions "have made it possible for decent people to work the docks again." In this ritualized scene, base corruption and human indignity, previously exposed in the "shape-up" and then condemned over a martyr's body, are finally made public before a tribunal that seeks to punish those responsible. In the Commission hearing room, mobsters, newspapermen, commissioners, and interested citizens all have a designated place in a tangibly ordered environment where legal processes are conducted in the open for all to see. Unlike the dank alleys and dingy asylums of waterfront criminals, the brightly lit and crowded room encourages photographers and reporters to publish what they see and hear, as investigators doggedly pursue the illegal activities of unions that do not keep accounting books or hold free elections. The demeaning competition between workers in the "shape-up" has now become a fair and open contest between equal adversaries made 
possible by a legal system that ensures individual rights. Totalitarian irreverence has thus been supplanted by democratic respect.

The filmic technique of On the Waterfront is as basic and effective as the narrative itself. There are no attempts at self-conscious aesthetics or pyrotechnics at the same time as there are no compromises in rendering the urban locale as anything but the concrete jungle it is. Closed or confining spaces; cramped camera angles; dark caverns; alleyways with piercing, blinding lights; laundry hanging on clotheslines that creates diagonal intrusions into what is already a restricted living space; underground passages that swallow automobiles and entrap unsuspecting denizens; and a combination of factory smoke, people's breath, trash-can fires, and damp fogginess that oppresses human emotions and obscures open vistas as well as vital perceptions - these are the visuals (orchestrated by the cinematographer Boris Kaufman in a unified palette of spectral grays) that menacingly accompany the story of On the Waterfront as it takes us into the cargo holds of ships, the slum dwellings of workers, the shack that serves as headquarters for the corrupt union leaders, the riverside piers, the seedy bars, the littered streets, even the rooftops of apartment buildings, with Manhattan looming in the background like an exotic foreign land beyond the longshoremen's reach. Everything about the film is thus grimy and oppressive (including the casting of real-life former heavyweight boxers as Johnny Friendly's bodyguards-cum-goons), with the waterfront presented as a harsh place where the strong prey upon the weak and a self-defeating code of silence or "D and D" ("Deaf and Dumb") prevails. We see and hear the subhuman malaise of this milieu, and we feel the suffering of the dockworkers as they mull about, daily, in what can only be called a species of fraternal hopelessness.

At the beginning of On the Waterfront, Terry Malloy not only is mired in this urban jungle of greed, deceit, and betrayal, but, barely articulate and thoroughly unschooled, he is also at a loss to understand it. Painfully confused about himself and his situation, he can only utter to Edie, over a drink, "Wanna know my philosophy of life? Do it to him before he does it to you." Yet beneath his layered exterior of toughness, Terry possesses traits that seem contradictory to his own philosophy: his fondness for the vulnerable yet "free," high-flying pigeons he raises in a rooftop coop; the tender way in a park he tries on, in place of a boxing glove, Edie's glove (one element in the film's "poetry of things," as opposed to words), as if he were "trying out" her superior moral values; the rejection he feels at being excluded from the confidence and protection of his older brother, together with whom he was raised in an orphanage after the death of their father (apparently himself a criminal).

As Brando interprets him, moreover, Terry Malloy also possesses an air of sadness. He is a man who, at one point, had the opportunity to rise above his condition through his skill as a prizefighter. Although he could have gained a sense of self-respect and self-worth as a contender for the middleweight boxing title, he was prevented from doing so by others-namely, Johnny Friendly and his crowd, including Charley Malloy - who made him take a "dive" so the mobsters could win big by betting on his opponent. Embittered but unself-pitying, Terry reveals his self-awareness ("I coulda been a contender") in a touching and justly famous scene with his brother in the back seat of a taxicab. Although well suppressed, then, the seed of something better resides in Terry. Left to himself, it is likely that he would have remained just another likeable but expendable dockworker and errand boy. But it is Edie's love that nurtures the seed of something better in Terry Malloy, that redeems him through love from the limitations of his own background.

Reduced in this way to its basics, On the Waterfront is a morality tale about how corruption can, indeed must, be fought and defeated when a man of courage and 
conscience emerges from the crowd to oppose the corruption. Although the narrative progresses in a linear manner without flashbacks and subplots, the film possesses a power that is announced from the opening scene, with its assertive orchestral percussion (from the musical score by Leonard Bernstein), in which Terry is dispatched to lure Joey Doyle into the set-up that will result in his murder. That power enabled On the Waterfront to dominate the Academy Awards of 1954 (it won Oscars for Best Motion Picture, Best Director, Best Actor, Best Screenplay, Best Supporting Actress, Best Black-and-White Art Direction/Set Decoration, Best Black-and-White Cinematography, and Best Film Editing, as well as an Oscar nomination for Best Score of a Dramatic or Comic Picture and three Oscar nominations for Best Supporting Actor); it brought credibility to the Method technique of acting taught at the Actors' Studio; and it certified the acting credentials of a number of talents trained for the theater, not least of which was Marlon Brando.

Even though On the Waterfront today is universally hailed as a milestone in film history, the picture's dénouement still taints its reputation as a classic. In publicly informing before a congressional committee on those who have exploited him and his fellow longshoremen, Terry Malloy is elevated to heroic proportions through an action that is typically classified-by both this film and society-as reprehensible. Although, on account of his public testimony, Terry is at first considered an outcast by everyone from the police assigned to protect him down to his neighbors (who refuse to speak to him), after he confronts Friendly he becomes the waterfront's lone pillar of strengthand one who immediately wins the support of all the other longshoremen.

The fact that, through the act of informing, Terry moves, perhaps too conveniently, from being a complex individual to becoming an emblem of Christian integrity and suffering - this fact has aggravated certain viewers over the years. It seems even to aggravate Terry: the "thesis" of evil (Johnny Friendly and criminal greed) is confronted in the film by its "antithesis" of good (Father Barry and Christian charity), and the new "synthesis" (Terry Malloy) miraculously fuses selfishness and selflessness; but, as an individual staggering beneath the weight of his moral decisions, Terry remains unconvinced of the rightness of either extreme. His ambivalence is complemented or underscored by Leonard Bernstein's music, whose rhythmic flourishes and haunting, melodic passages add nuance and density to the protagonist's actions and, in general, enliven the story's development.

The major slow themes in the Bernstein score are the "Waterfront Theme" (which opens the film, appears in segments throughout, and reappears in altered form during the final scene) and the "Edie/Love Theme" (which announces Edie's entrances onto the waterfront stage). The two themes are played together when Terry and Edie discover the dead pigeons (killed in retaliation for his being a "stool pigeon") on the roof, offering a musical reprise of the kiss that had momentarily united the couple - and the values they represent - in her apartment. After the kiss, after these two melodies are intertwined, Charlie's own dead body is discovered by Terry and Edie, and it is at this point that he resolves to gain personal revenge for his brother's murder on Johnny Friendly himself. In this way, Bernstein's score attributes motivation to Terry's actions: without such commentative musical statements, the causal connections between characters' thoughts and actions might be missed.

In contrast to the two major "slow" themes, an aggressive and assertive one, the "Murder Theme," etches an acoustic portrait of the corrupted, urban environment in $O n$ the Waterfront. The "Murder Theme," marked presto barbaro in the sheet music, is first heard at the start as the Friendly gang emerges from its dingy waterfront shack. The three-voice fugato, with its rhythmic irregularity, creates an unsettling atmosphere and 
hauntingly presages Joey Doyle's murder. Like the "Waterfront Theme" and the "Edie/Love Theme," the "Murder Theme" is thus attached to one of the contending factions of the narrative. The violent and unscrupulous mobsters are identified with the murder theme; the spiritual and incorruptible Edie is associated with the love theme; and the setting in which these two antithetical forces collide is represented by the waterfront theme.

Atmospheric unity, like that gained from Boris Kaufman's misty black-andwhite cinematography (in his first American feature film) and Richard Day's dreary sets, is communicated in the music through a fourth, independent "Snap Theme." Even though this active, agitated, even disturbing passage is the most pervasive musical theme in the picture, it is not used to comment on the characters or the plot. This unique combination of melody and rhythm is heard, for example, during the attack on the basement church meeting called by Father Barry; later it is given a honky-tonk rendering for the saloon scene. The "Snap Theme" is also played rapidly during the fight scene between Terry and Johnny Friendly, with a slower rendition heard after the fight when Terry is discovered lying half in the water. Such an added musical touch, with its complex metric pattern, accents the dramatic peaks - and valleys - of the narrative and, through the atmosphere it creates, contributes to the overall aesthetic unity of On the Waterfront as well as the characterological coherence of its protagonist.

Some have argued, however, that the film's very attention to the individual moral struggles of Terry Malloy, as accentuated by Bernstein's musical score, weakened its depiction of waterfront corruption. According to this view, On the Waterfront's concentration on a singular dominating character brought close to the camera's eye, and rendered triumphant in a seemingly optimistic ending, made it aesthetically inconvenient - if not impossible - to set Terry's story in its proper social and historical context, the actual conditions that created the corrupt, oppressive system down at the docks. (For example, how did the shipping rackets come to power? How did they become so effective? Apart from the longshoremen, with whom exactly did the waterfront racketeers deal and why?) So much did this appear to be the case that the critic-become-filmmaker Lindsay Anderson was moved to describe the film's violent conclusion as "implicitly (if unconsciously) fascist" (128), as the ignorant and befuddled longshoremen transferred loyalties so easily from one oppressor (Johnny Friendly) to another potential oppressor (Terry Malloy) without experiencing any sense of their own liberation.

From the point of view of others, the film's structural argument exposes demeaning labor conditions, blames corrupt individuals for the failure of an approved institutional structure - a union-to improve those conditions, and suggests a legal solution to the problem of worker exploitation by both unions and employers. Yet, for these critics, On the Waterfront tacks on an ambivalent ending that, with its suggestion of continued corruption (in the person of the unnamed and unaccused but twice-seen "Mr. Upstairs" [an allusion either to millionaire financier William McCormick or New York mayor William O'Dwyer], Johnny Friendly's superior, who remains in power at the end if Friendly does not), posits the idea that the oppression of workers is inherent in the capitalist system. Thus the film becomes a curious mixture of assertions favoring social reform and suggestions as to the ultimate futility of such reforms (not to speak of its contradictory mixture of altruistic Christian allegory and revenge-minded fantasy) a combination film noir and social-problem picture, as it were. Bernstein's closing musical passages themselves accentuate the tenuous nature of the reformer Malloy's victory, as they avoid a strong, tonic cadence that would imply a stable resolution and substitute instead a dissonant tone combined with a staccato rhythm. 
Still other critics have cited the parallels to Elia Kazan and Budd Schulberg's political situation outside the film and have objected not only to On the Waterfront's ending as an unconvincing metaphorical effort to vindicate their own informing to HUAC, but also to the whole film's making of mobster control over the waterfront analogous to Communist party control over the individual. (In the play The Crucible [1953], incidentally - an apparent study of witchcraft in Puritan Massachusetts - Arthur Miller himself tried to link the seventeenth-century Salem witch-hunts with McCarthyist Red-baiting, to explore the connection between equally hysterical and oppressive responses to individual acts of conscience, conviction, or resistance.) Whatever interpretation one prefers, it is worth noting that in writing the novelization of his screenplay for the movie, Schulberg chose to end it not with Terry's heroic rise to leadership but with his ignoble death (similar to Peter Panto's): he is stabbed twentyseven times with an ice pick, only then to have his body deposited in a barrel of lime in a New Jersey swamp.

A few critics have even attacked On the Waterfront for not being the boxing movie it could have been. According to this argument, On the Waterfront has nearly every ingredient of the traditional boxing picture - except the main ingredient, boxing itself. Certainly Marlon Brando's character is filled with all the romance associated with such memorable screen pugilists as Richard Barthelmess in The Patent Leather Kid (1927), Wallace Beery in The Champ (1931), William Holden in Golden Boy (1939), James Cagney in City for Conquest (1940), John Garfield in Body and Soul (1947), Robert Ryan in The Set-Up (1949), Kirk Douglas in Champion (1949), Paul Newman in Somebody Up There Likes Me (1956), Sylvester Stallone in Rocky (1976), even Max Baer in person in The Prizefighter and the Lady (1933). Though their apparent subject is physical punishment, moreover, boxing movies have always been about the ordeals and humiliations that lead to spiritual redemption-just like On the Waterfront. For the boxing critics of Kazan's film, the fact that its best-known scene is the one between Brando and Rod Steiger in the taxi, where the brothers discuss Terry's aborted fighting career, speaks for itself. (It speaks in other pictures, as well: the untraditional boxing film Raging Bull [1980], for one, in which the Jake LaMotta character sits before a mirror at the very end and recites all of Malloy's "I coulda been a contender" speech.)

Despite the criticisms On the Waterfront has received since its first showing in July of 1954, the dramatic power of the film - and of Brando's central performanceendures, undiminished. Whether one sees it, finally, as a moral tale, a semidocumentary crime melodrama, a social-problem picture, a boxing film manqué, a Christian allegory, a political allegory, or a revenge fantasy, On the Waterfront has found its way into the ranks of cinema classics - where it remains, over sixty years after its initial release.

\section{Bibliography and Works Cited}

Anderson, Lindsay. "The Last Sequence of On the Waterfront." Sight and Sound, 24.3 (Jan.-March 1955): 127-130.

Baer, William, ed. Elia Kazan: Interviews. Jackson: University Press of Mississippi, 2000.

Biskind, Peter. "The Politics of Power in On the Waterfront." Film Quarterly, 29.1 (1975): 25-38.

Braudy, Leo. On the Waterfront. 2005. London: British Film Institute, 2008. 
Bushard, Anthony. Leonard Bernstein's On the Waterfront: A Film Score Guide. Lanham, Md.: Scarecrow Press, 2013.

Ciment, Michel. Kazan on Kazan. New York: Viking, 1974.

Coughlin, Paul. "An Ideological Critique: On the Waterfront." Screen Education, no. 60 (2010): 139-145.

Dombrowski, Lisa, ed. Kazan Revisited. Middletown, Conn.: Wesleyan University Press, 2011.

Fraser, Peter. "On the Waterfront (1954)." In Fraser's Images of the Passion: The Sacramental Mode in Film. Westport, Conn.: Praeger, 1998. 140-151.

Hamilton, William. "On the Waterfront." Film Music, 14 (Sept.-Oct. 1954): 3-15.

Hey, Kenneth. "Ambivalence as a Theme in On the Waterfront (1954): An Interdisciplinary Approach to Film Study." American Quarterly, 31.5 (Winter 1979): 666-696.

Hurley, Neil P. "On the Waterfront: Rebirth of a 'Contenduh'." In Image \& Likeness: Religious Visions in American Film Classics. Ed. John R. May. New York: Paulist Press, 1992. 96-103.

Johnson, Malcolm. Crime on the Labor Front. New York: McGraw-Hill, 1950.

---------. On the Waterfront: The Pulitzer Prize-Winning Articles That Inspired the Classic Film and Transformed the New York Harbor. New York: Chamberlain Bros., 2005.

Kazan, Elia. Elia Kazan: A Life. New York: Alfred A. Knopf, 1988

Kazan on Directing. New York: Alfred A. Knopf, 2009.

Kazin, Alfred. "On the Waterfront: An Angry and Idealistic Movie-The Kind They Don't Make Anymore." Esquire, 97 (Jan. 1982): 77-78.

Maland, Charles J. "On The Waterfront (1954): Film and the Dilemmas Of American Liberalism in the McCarthy Era." American Studies in Scandinavia, 14.2 (1982): 107-127.

Michaels, Lloyd. Elia Kazan: A Guide to References and Resources. Boston: G. K. Hall, 1985.

Neve, Brian. Elia Kazan: The Cinema of an American Outsider. London: I. B. Tauris, 2009.

Pauly, Thomas H. An American Odyssey: Elia Kazan and American Culture. Philadelphia: Temple University Press, 1983.

Rapf, Joanna E., ed. On the Waterfront. New York: Cambridge University Press, 2003.

Raymond, Allen. Waterfront Priest. New York: Henry Holt, 1955.

Schickel, Richard. Elia Kazan: A Biography. New York: HarperCollins, 2005.

Schulberg, Budd. On the Waterfront: Final Shooting Script. 1980. London: Faber \& Faber, 1991.

--------. On the Waterfront: A Play. 1983. Chicago: Ivan R. Dee, 2001. On the Waterfront: A Novel. 1955. Chicago: Ivan R. Dee, 2010.

Simmons, Gary. "Conscience, Confession, and Context in On the Waterfront." Screen Education, no. 56 (2009): 91-96.

-------- "Back to the Waterfront: A Close Reading of On the Waterfront." Screen Education, no. 57 (2010): 137-143.

Tailleur, Roger. "Elia Kazan and the House Un-American Activities Committee." Trans. Alvah Bessie. Film Comment, 4.1 (Fall 1966): 43-59.

Credits: On the Waterfront (1954)

Director: Elia Kazan 
Screenplay: Budd Schulberg, suggested by articles in the twenty-four part series "Crime on the Waterfront," written by Malcolm Johnson and published in the New York Sun in 1948

Cinematographer: Boris Kaufman

Editor: Gene Milford

Music: Leonard Bernstein

Art Director: Richard Day

Costume Designer: Anna Hill Johnstone

Running time: 108 minutes

Format: $35 \mathrm{~mm}$, in black and white

Cast: Marlon Brando (Terry Malloy), Eva Marie Saint (Edie Doyle), Karl Malden (Father Barry), Lee J. Cobb (Johnny Friendly, a.k.a. Michael J. Skelly), Rod Steiger (Charley "the Gent" Malloy), John Hamilton ("Pop" Doyle), Pat Henning ("Kayo" Dugan), James Westerfield (Big Mac), Leif Erickson (Glover), Tony Galento (Truck), Tami Mauriello (Tillio), John Heldabrand (Mott), Rudy Bond (Moose), Don Blackman (Luke), Arthur Keegan (Jimmy), Abe Simon (Barney), Martin Balsam (Gillette), Fred Gwynne (Slim), Thomas Handley (Tommy Collins), Anne Hegira (Mrs. Collins), Pat Hingle (Jocko), Zachary Charles (Dues collector), Dan Bergin (Sidney), Barry Macollum (Johnny's banker), Mike O’Dowd (Specs), Nehemiah Persoff (Cab driver).

Feature Filmography: Elia Kazan (1909-2003)

A Tree Grows in Brooklyn (1945)

Boomerang! (1947)

Gentleman's Agreement (1947)

Pinky (1949)

Panic in the Streets (1950)

A Streetcar Named Desire (1951)

Viva Zapata! (1952)

On the Waterfront (1954)

East of Eden (1955)

Baby Doll (1956)

A Face in the Crowd (1957)

Wild River (1960)

Splendor in the Grass (1961)

The Last Tycoon (1976)

Filmography: Key Hollywood Social-Problem Pictures of the 1940s and '50s

The Lost Weekend (1945), directed by Billy Wilder

The Best Years of Our Lives (1946), directed by William Wyler

Crossfire (1947), directed by Edward Dmytryk

Gentleman's Agreement (1947), directed by Elia Kazan

Body and Soul (1947), directed by Robert Rossen

Boomerang! (1947), directed by Elia Kazan

Kiss of Death (1947), directed by Henry Hathaway

Brute Force (1947), directed by Jules Dassin

The Naked City (1948), directed by Jules Dassin

The Snake Pit (1948), directed by Anatole Litvak

Force of Evil (1948), directed by Abraham Polonsky

Pinky (1949), directed by Elia Kazan 
Knock on Any Door (1949), directed by Nicholas Ray

Lost Boundaries (1949), directed by Alfred L. Werker

Home of the Brave (1949), directed by Mark Robson

Intruder in the Dust (1949), directed by Clarence Brown

The Set-Up (1949), directed by Robert Wise

The Men (1950), directed by Fred Zinnemann

The Asphalt Jungle (1950), directed by John Huston

The Lawless (1950), directed by Joseph Losey

On the Waterfront (1954), directed by Elia Kazan

The Defiant Ones (1958), directed by Stanley Kramer

R. J. CARDULLO has had his work appear in such journals as the Yale Review, Cambridge Quarterly, Film Quarterly, and Cinema Journal. For twenty years, from 1987 to 2007, he was the regular film critic for the Hudson Review in New York. Cardullo is the author or editor of a number of books, including Soundings on Cinema: Speaking to Film and Film Artists (SUNY Press, 2008) and In Search of Cinema: Writings on International Film Art (McGill-Queens UP, 2004). He is also the chief American translator of the film criticism of the Frenchman André Bazin. Cardullo's own film criticism has been translated into the following languages: Russian, German, Chinese, Turkish, Spanish, Korean, and Romanian. Cardullo earned his doctoral degree from Yale University and received his B.A. from the University of Florida. He taught for four decades at the University of Michigan, Colgate, and New York University, as well as abroad.

e-mail: robertjcardullo@gmail.com 